\title{
Federal Rule of Evidence 804(b) (3) and Inculpatory Statements Against Penal Interest
}

The inadmissibility of hearsay ${ }^{1}$ statements has long been a dominant principle of the law of evidence. ${ }^{2}$ Because such statements are not made under oath before the factfinder and are not subject to cross-examination, they are viewed as unrehable. ${ }^{3}$ Some hearsay statements, because of their content or the context in which they are inade, are thought to be sufficiently reliable to be presented to the factfinder. The result has been the creation of exceptions to the rule excluding hearsay evidence. ${ }^{4}$

Federal Rule of Evidence 804(b)(3) codifies one such exception. This rule admits into evidence declarations against penal interest. ${ }^{5}$ It is based on the cominon sense belief that people do not rashly or falsely make statements against their penal interest. ${ }^{6}$ Despite its ostensible

1. Hearsay is defined in FED. R. Evid. 801(c) as ". . . a statenent, other than one made by the declarant while testifying at the trial or hearing, offered in evidence to prove the truth of the matter asserted."

2. See generally C. McCormick, Handbook of the Law of EVIDENCE $\$ 244$ (2d ed. 1972); W. Richardson, The LAW OF Evidence $\$ 239$ (7th rev. ed. 1948); 5 J. Wigmore, EviDENCE § 1361 (3d ed. 1940).

3. The oath, the opportunity for the jury to examine the declarant's demeanor, and the opponent's cross-examination are all viewed as guarantors of reliability. C. MCCoRMick, supra note 2, at § 245. See also B. JoNEs, The LAw OF EVIDENCE § 268 (5th rev. ed. 1958); 5 J. WiGMORE, supra note 2, at $\S 1363$ (emphasizing the importance of the oath and cross-examination).

4. $5 \mathrm{~J}$. WiGMORE, supra note 2 , at $\$ 1420$. Wigmore notes that the presence of a "circumstantial probability of trustworthiness" and the factinder's need for the statement have been the major factors which have allowed for the creation of hearsay exceptions.

5. Rule 804(b)(3) admits any "statement which . . . so far tended to subject [the declarant] to ... criminal liability ... that a reasonable man in his position would not have made the statement unless he believed it to be true." FED. R. Evid. 804(b)(3). The rule sets forth an additional requirement for statements against penal interest offered to exculpate the accused: "A statement tending to expose the declarant to criminal liability and offered to exculpate the accused is not admissible unless corroborating circumstanccs clearly indicate the trustworthiness of the statement."

6. The hearsay exception admitting statements against pecuniary or proprietary interest is well established. See generally Jefferson, Declarations Against Interest: An Exception to the Hearsay Rule, 58 HARv. L. Rev. 1 (1944); Morgan, Declarations Against Interest, 5 VAND. L. Rev. 451 (1952). Initially, however, statements against penal interest were not included withm its scope. The Sussex Peerage case, 8 Eng. Rep. 1034 (1844). The absence of a principled basis for this development and the horrifying results it produced on occasion gave rise to vehement criticism 
clarity, rule 804(b)(3) contains an important anbiguity. The rule does not refer to a troublesome type of declaration agamst penal interest: the inculpatory stateinent against the penal interest of the deelarant which also implicates and is sought to be admitted against the defendant. ${ }^{7}$ Given that a provision to exclude sueh inculpatory statements had been part of the rule as originally drafted-only to be excised, reinserted, and once more omitted in the drafting process-the present rule leaves unanswered a number of important questions. Are all inculpatory statements admissible under rule 804(b)(3)? Are only noncollateral ${ }^{8}$ inculpatory statements adinissible? If even collateral imculpatory statements are admissible, what are the requirements for admissibility?

This Comment atteinpts to answer these questions. In this effort, the labyrinthine drafting process which produced rule 804(b)(3) is exammed to determine the intent of the groups involved in its drafting. Next, the treatinent by federal courts of declarations against penal interest under rule 804(b)(3) is analyzed to determine how courts have decided these questions. Fimally, this Comment proposes a inethod for dealing with inculpatory stateinents under rule 804(b)(3).

by commentators. C. MCCoRMICK, supra note 2, at $\$ 278 ; 5 \mathrm{~J}$. WIGMORE, supra note 2, at $\S \S 1476,1477$. See also Justice Holmes' often-quoted dissent in Donnelly v. United States, 228 U.S. 243, 277-78 (1913). By the middle of this century, the hesitant, though unmistakable, trend was to include declarations against penal imterest within the exception. C. MCCoRMICK, supra note 2 , at $\S 278$.

7. The confusing nature of the terminology used to deseribe declarations against interest has been intensified by the carelessness of some courts. Essential to an analysis of the issues involved is an understanding of the relevant classifications. An inculpatory statentent is one which implicates both the declarant and the defendant in criminal activity and is admitted against the defendant. Such statements can be divided into collateral and noncollateral statements. In a noncollateral inculpatory statement, the faets inculpating the defendant are found in the portion of the statement directly against the declarant's iinterest. In his treatise, Distriet Judge Jack Weinstein presents as an exainple of such a statement one in whieh the declarant states that he has stolen goods, with the statement admitted against a defendant charged with possession of the stolen goods. 4 J. WEINSTEIN \& M. BERGER, WEINSTEIN'S EVIDENCE: COMMENTARY ON RULES

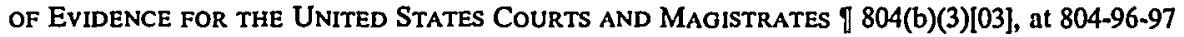
(1977) [hereinafter cited as $4 \mathrm{~J}$. WeINSTEIN]. Here, the fact that the declarant has stolen the items is disserving to the declarant and inculpates the defendant. Because sueh statements can arise only where a defendant is accused of certain less common crimes, they do not appear often in the cases.

The more common type of imculpatory statement is the collateral inculpatory declaration. Here, the inculpatory material is not found in the portion of the statement directly against the declarant's interest, but appears instead in another portion of the statement. An exaunple of such a statement would be the declarant's assertion that "John and I robbed the bank" admitted in John's trial for bank robbery. In this exaunple the relevant material is not contained in the disserving segment ("I robbed the bank."); instead, it is in the collateral portion ("John robbed the bank.").

Exculpatory statements are deelarations against the declarant's interest whieh indieate that the defendant is not responsible for the crime charged. These also can be divided into the collateral and noncollateral classifications described above.

8. For a description of collateral and noncollateral statements, sce note 7 supra. 


\section{The Drafting of Rule 804(b)(3)}

The original Advisory Committee ${ }^{9}$ draft of rule 804(b)(3) made clear that inculpatory statements were not to be admitted at trial. The final sentence of the draft rule provided: "This example does not imclude a statement or confession offered against the accused in a criminal case, made by a codefendant or other person implicating both himself and the accused." 10 This final sentence was retained in the March 1971 Advisory Committee draft, ${ }^{11}$ but it was omitted from an unpublished draft which the committee forwarded to the Supreme Court in Noveinber 1971. ${ }^{12}$ The sentence was again absent when the Supreine Court promulgated the official Advisory Committee draft of the Federal Rules of Evidence in November 1972.13 The rules were submitted for congressional amendinent and approval in 1973.14 The House remserted the final sentence of rule $804(\mathrm{~b})(3) .{ }^{15}$ The Senate found this addition unacceptable and deleted it from its version of the rule. ${ }^{16}$ The conference committee adopted the Senate position. ${ }^{17}$ Therefore, as passed by Congress, rule 804(b)(3) contained no specific reference to inculpatory statements.

The ambiguity created by this legislative history is not easily resolved. One view is that the drafters believed that inculpatory statements are reliable and sought to admit them. The antithetical view is that the drafters thought imculpatory statements to be insufficiently trustworthy to warrant inclusion in the 804(b)(3) exception; the drafters, therefore, omitted thc final sentence, believing that such an explicit statement was not needed because this result was already mandated by the rules. ${ }^{18}$ As each of the drafting units' work is examined in the

9. The Advisory Committee and a Reporter for the committee were appointed by Chief Justice Warren im March 1965 to draft rules of evidence for the federal courts. The committee met between June 1965 and December 1968, revising the draft prepared by the Reporter, Professor Edward L. Cleary. The first draft completed by the committee was published in 1969. Proposed Amendments to the Federal Rules of Evidence: Hearings on H.R. 5463 Before the Senate Comm. on the Judiciary, 93d Cong., 2d Sess. 37, 40-41 (1974) [hereinafter cited as Senate Hearings] (statement of Judge Albert B. Maris).

10. Proposed Fed. R. Evid. 804(b)(4) (1969 draft), 46 F.R.D. 161, 378 (1969). The rule was renumbered as $804(\mathrm{~b})(3)$ before it emerged in its final form.

11. Proposed Fed. R. Evid. 8-04(b)(4) (1971 draft), 51 F.R.D. 315, 438-39 (1971).

12. Senate Hearings, supra note 9, at 40 (statement of Judge Albert B. Maris).

13. Fed. R. Evid. 804(b)(3) (1972 draft), 56 F.R.D. 183, 321 (1972).

14. Senate Hearings, supra note 9, at 6 (statement of William L. Hungate).

15. HOUSE COMM. ON THE Judiclary, RePORT ON FEDERAL Rules OF EVIDENCE, H.R. REP. No. 650, 93d Cong., 1st Sess. 16 (1973) [hereinafter cited as House REPORT].

16. SENATE COMM. ON THE Judiciary, Report on FEDERAL Rules OF EVIDENCE, S. REP. No. 1277, 93d Cong., 2d Sess. 21-22 (1974) [hereinafter cited as SENATE REPORT].

17. Comm. of Conference, Report on Federal Rules of Evidence, H.R. Rep. No. 1597, 93d Cong., 2d Sess. 12 (1974) [hereinafter cited as CONFERENCE REPORT].

18. This is the position taken by District Judge Jack Weinstein and Professor Marilyn A. 
search for "intent," it will be instructive to evaluate the extent to which the material encountered supports either of these opposing views.

\section{A. The Advisory Committee}

The Advisory Committee's work on 804(b)(3) is in some ways the most illummating. The committee's 1969 draft explicitly excluded inculpatory statements. In the Note accompanying this draft, the committee stated that statements against penal interest might include portions implicating an accused other than the declarant. ${ }^{19}$ Such collateral portions would be admissible, acknowledged the committee, under existing doctrine applicable to statements against pecuniary and proprietary interest. ${ }^{20}$ The committee then made the only statement to be found in any of the official comments to the rules which denigrated the rehability of inculpatory statements. Referring to the dissent by Justice White in Bruton v. United States, ${ }^{21}$ the committee argued that statements by codefendants implicating each other were unreliable "because of the readily supposed advantages" of such statements, and concluded that therefore inculpatory statements should not be admitted. ${ }^{22}$

The Advisory Committee reversed its position on the reliability of mculpatory statements and omitted the final sentence of rule 804(b)(3) in its unpublished October $1971 \mathrm{draft}$ and im its final draft promulgated by the Supreme Court in November $1972 .{ }^{23}$ The revised Note accom-

Berger in their treatise on the Federal Rules of Evidence. Noting that the first two drafts of rule 804(b)(3) contained the final sentence, Weinstein concludes:

Except in the inost unusual situation, exclusion of the statement would have been the result obtained under the present rule. When Congress added the final sentence to Rule 804(b)(3) it made this point clear. But it was dropped by Congress on the grounds that it was not needed . . . . In context, this means that the Rule should be interpreted to include this language.

4 J. Weinstein, supra note 7, f 804(b)(3)[3] at 804-93. Despite this bald assertion, Weinstein does not attempt to explore what motivated efforts to include the final sentence, to determine how the various drafting bodies felt about inculpatory statements. In fact, a close examination of Wcinstein's analysis indicates that his argument about the exclusion of inculpatory statements relies chiefly upon the confrontation clause, id. at 804-94 to -95 , and rule 403 , id. at 804-95 to -97, and fails to deal with the ambiguity of rule $804(b)(3)$.

19. Advisory Committee's Note to Proposed Fed. R. Evid. 8-04(b)(4) (1969 draft), 46 F.R.D. 161, 386 (1969).

20. "[The third-party confession] may include statements implicating [the accused] and under the general theory of declarations against interest they would be admissible as related statements." Id. See also note 109 infra.

21. 391 U.S. 123 (1968).

22. Advisory Committee's Note to Proposed Fed. R. Evid. 8-04(b)(4) (1969 draft), 46 F.R.D. 161, 386 (1969).

23. Following the publication of its first draft in 1969, the committee issued another draft in March 1971. The final sentence was retamed in that draft. Proposed Fed. R. Evid. 804(b)(4) (1971 draft), 51 F.R.D. 315, 438-39 (1971). After publication of the March 1971 draft, criticism and suggestions once more were submitted to the committee. Responding to the comments, the committee met again in September 1971 and incorporated certain changes in a new draft approved by the Judicial Conference in October 1971. This draft was not published. Instead it was made available to about 600 people for further comment. Aside from changes in rules 510 and 
panying the final draft of the rule explained:

Thus a statement admitting guilt and implicating another person, made while in custody, may well be motivated by a desire to curry favor with the authorities and hence fail to qualify as against interest. See the dissenting opinion of Mr. Justice White in Bruton. On the other hand, the same words spoken under different circumstances, e.g., to an acquaintance, would have no difficulty in qualifying. The rule does not purport to deal with questions of the right to confrontation. ${ }^{24}$

This Note makes clear that the Advisory Committee intended some inculpatory statements, collateral as well as noncollateral, to be admissible under 804(b)(3). In fact, the language used by the committee suggests that all statements truly against interest that contain neutral or disserving collateral portions were intended to be admissible. The reluctance in previous drafts to admit inculpatory statements was here explained as a fear that some inculpatory stateinents, though ostensibly admitting a crime, might be nnotivated by the declarant's desire to appease law enforcement officials. Such stateinents would not qualify under the rule because they would not be truly against interest. The misgivings previously expressed about the reliability of inculpatory statements were thus withdrawn as unwarranted.

The seemingly clear picture of the committee's imtent on this issue which emerges froin the revised Note is solnewhat tarnished by allegations that political unachinations influenced the committee's change of position. In a stateinent before the House Subcommittee on Criminal Justice, Charles R. Halpern and George T. Frainpton, representing the Washington Council of Lawyers, argued that the committee's revision of $804(\mathrm{~b})(3)$ was motivated not by a view that inculpatory statements were reliable but rather by political pressures. ${ }^{25}$ Halpern and Frampton criticized various changes that were made after the completion of the Marcl 1971 draft. Tley argued that the Justice Departinent and Senator McClellan, an influential mennber of the Senate Judiciary Committee, coerced the Advisory Committee into making certain changes, with McClellan threatening to obstruct the entire project if his recommendations were not accepted. ${ }^{26}$ This pohtical pressure allegedly was exerted after publication of the March 1971 draft $^{27}$ and bore

609 , this draft was issued by the Supreme Court as the completed work of the Advisory Committce and the Judicial Conference in November 1972. Senate Hearings, supra note 9, at 41-42 (statement of Judge Albert B. Maris).

24. Proposed Fed. R. Evid. 804(b)(4) (1972 draft), 56 F.R.D. 183, 328 (1972).

25. Proposed Rules of Evidence: Hearings on H.R. 5463 Before the Subcomm. on Criminal Justice of the House Comm. on the Judiciary, 93d Cong., 1st Sess. 179 (1973) theremafter cited as House Hearings] (statement of Charles R. Halpern and George T. Frampton).

26. Id. at 180 . Halpern and Frampton insisted that the legislation requiring congressional approval for the rnles was viewed as a signal that Senator McClellan was willing and able to exert pressure to effect changes in certain provisions.

27. Indeed, Senator McClellan did communicate to the Advisory Committee his displeasure 
fruit in the substantial amendments appearing in the unpublished October 1971 draft and the final draft. ${ }^{28}$ The omission of the last sentence of 804(b)(3) was one amendment to which Halpern and Frampton pointed.

The claims of Halpern and Frampton support an argument that the Advisory Committee's statement of intent is a suspect and inadequate base on which to build an interpretation of the silence of 804(b)(3). An awareness of their claims renders more important the effort to ascertain the intent of the other drafting bodies involved: the House, Senate, and conference committees.

\section{B. The Congressional Committees}

Although there is some doubt about the Advisory Committee's conelusions regarding the rehiability of inculpatory statements, the Advisory Committee at least focused on that key question. In contrast, the congressional committees paid little attention to the rehability issue. Their work concentrated on the confrontation clause of the United States Constitution.

The introduction of this issue was apparently due to a reference to Bruton v. United States ${ }^{29}$ and Douglas v. Alabama ${ }^{30}$ im the Note to the Advisory Committee's original version of rule $804(\mathrm{~b})(3) .{ }^{31}$ In both Bruton and Douglas, ${ }^{32}$ the Supreme Court held that the confrontation

with the final sentence. Proposed Rules of Evidence: Supplement to Hearings on H.R. 5463 Before the Subcomm. on Criminal Justice of the House Comm. on the Judiciary, 93d Cong., 1st Sess. 60 (1973) [hereinafter cited as Supplement 10 House Hearingsl (letter of Senator John L. McClellan to Judge Albert B. Maris (Aug. 12, 1971)). Senator McClellan argued that the final sentence should be omitted. Apparently inferring from the awkward references to Bruton and Douglas in the March 1971 draft that the Advisory Committee's position was based upon its reading of the confrontation clause, Senator McClellan asserted that the confrontation clause simply did not mandate exclusion of all inculpatory statements. Id. at 60 . Deputy Attorney General Kleindienst expressed similar sentiments. Letter from Deputy Attorney General Richard G. Kleindienst to Judge Albert G. Maris (Aug. 9, 1971), reprinted in 117 CoNG. REC. 33648, 33657 (1971).

28. Among the evidence presented by Halpern and Frampton suggesting the effects of such pressure is a letter from Judge Albert B. Maris to Professor Charles A. Wright acknowledging this pressure and stating: “" [ [ ] t may well be that we have to make major concessions in the Evidence draft." House Hearings, supra note 25, at 180-81 (statement of Charles R. Halpern and Gcorge T. Frampton).

29. 391 U.S. 123 (1968).

30. 380 U.S. 415 (1965).

31. Advisory Committee's Note to Proposed Fed. R. Evid. 8-04(b)(4) (1969 draft), 46 F.R.D. 161, 386 (1969).

32. In Bruton the Court held that the admission in a joint trial of a codefendant's confession violated the defendant's confrontation clause rights despite the trial court's admonition to the jury that the confession was inadmissible against the defendant.

In Douglas the prosecutor called to testify the defendant's alleged accomplice who had been convicted im an earher trial. Since the witness refused to answer questions the prosecutor crossexamined him as a hostile witness. During this cross-examination, the prosecutor read the accomphice's purported confession to the jury. The Court held that this conduct violated the confrontation clause in denying the defendant the right to cross-examine the declarant. 
clause was violated by the admission into evidence of statements made by declarants who did not testify. ${ }^{33}$ The only relevance of the cases to the Advisory Committee's treatment of inculpatory stateinents was that both involved inculpatory statements and that Justice White's dissent im Bruton had deprecated the reliability of codefendants' inculpatory statements. Because the Advisory Committee did not invoke the confrontation clause as a basis for excluding inculpatory statements, the reference to Bruton and Douglas was gratuitous.

When the final Advisory Committee draft was sent to the House of Representatives, the House subcommittee linked the confrontation clause to the final sentence of rule 804(b)(3). ${ }^{34}$ In the tentative subcommittee draft of the rules completed on June $28,1973,{ }^{35}$ the final sentence of rule $804(\mathrm{~b})(3)$ was reinserted. ${ }^{36}$ The justification advanced for this amendment was set out succinctly in the subcommittee Note: "The Subcommittee also determined to add to the Rule the final sentence froin the $1971 \mathrm{draft}$, designed to codify the [confrontation clause] doctrine of Bruton v. United States . . .."37 The Senate Judiciary Committee, to which the House bill was sent, deleted the final sentence. ${ }^{38}$ In

33. In both cases, the statement did not fall within an exception to the hearsay rule as to the defendant agaimst whom it was admitted.

34. This linkage had in fact emerged in the summer of 1971 in letters written by Senator McClellan and Deputy Attorney General Richard Kleindienst to the Advisory Committee. See note 27 supra.

35. The House subcommittee held hearings in 1973 on February 7, 8, 22, and 28, and March 7 and 15. After extensive deliberation, the subcommittee passed the proposed rules on to the Judiciary Committee for further consideration. After some additional markup sessions, the bill was reported to the House. On February 6, the bill was passed, 377-13. House Hearings, supra note 25, at 6 (statement of William L. Hungate).

36. Proposed Fed. R. Evid. 804(b)(3), Tentative Subcommittee draft of H.R. 5463 in Supplement to House Hearings, supra note 27, at 175.

37. Id. at 176. Once the focus of analysis was distorted in this manner, debate proceeded along this path. Those who responded to the treatment of inculpatory statements in the subcommittee's tentative draft addressed the confrontation clause issue and completely ignored the reliability question. The Attorney General of Kentucky praised the amendment as "[a] good addition . . principally codifying the doctrine of Bruton," though lie noted that the language might have been too inflexible to reflect subsequent cases which had "manicured [Bruton's] import." Supplement to House Hearings, supra note 27, at 216-17 (letter from Ed. W. Hancock, Attorney General of Kentucky, to Subcommittee on Criminal Justice, (July 20, 1973)). See also id. at 309-10 (letter from Committee on Federal Courts, The Association of the Bar of the City of New York, to William L. Hungate). Acting Deputy Attorney General William D. Ruckelshaus also asserted that the final sentence was an attempt to codify Bruton, but he took a different approach. Id. at 351-52 (letter from William D. Ruckelshaus, Acting Deputy Attorney General, to William L. Hungate, (September 13, 1973)). Ruckelshaus argued that the final sentence should be omitted because a question as "complicated and marked by nuance" as the interrelationship of hearsay statements, hearsay exceptions, and the confrontation clause was not an apt subject for a statute. Id. at 352. Professor Kemieth W. Graham, Jr. expressed similar sentiments, arguing that the final sentence was "an inadequate statement of Bruton" and inconsistent with the general approacl of the rules to avoid dealing with confrontation clause problems. Id. at 205 (Letter froin Professor Kenneth W. Graham, Jr. to William L. Hungate, (July 16, 1973)).

38. Senate RePORT, supra note 16, at 21-22. The Senate Judiciary Committee devoted less 
its report, the Senate committee indicated its understanding that the House had viewed the final sentence as mandated by the confrontation clause. ${ }^{39}$ The committee did not justify its deletion by argumg that inculpatory stateinents were sufficiently reliable to be admissible. Instead, it insisted that the House's attempt to imcorporate constitutional doctrine was inconsistent with the drafters' reluctance to codify constitutional principles in the rules. ${ }^{40}$ The committee also noted that the final sentence failed to account for exceptions to Bruton carved out by the Supreme Court in subsequent cases. ${ }^{41}$

The passage of the rules in the Senate with the final sentence excised froin $804(\mathrm{~b})(3)$ required that the issue be resolved by a conference committee. The conference committee adopted the Senate version, omitting the final sentence from the statute. The conferees justified this resolution with the reasoning of the Senate committee: the rules should not atteinpt to codify constitutional principles on this question. ${ }^{42}$

The congressional committees' preoccupation with the confrontation clause is disheartening in two respects. First, this concern reflected a sloppy reading of Bruton and other confrontation clause cases, and caused the committees to focus on an irrelevant issue. Second, it allowed the congressional committees to avoid addressing explicitly the important issue presented: the reliability of inculpatory statements.

At the time rule 804(b)(3) was being drafted, the relationship between hearsay exceptions and the confrontation clause had not been defined clearly. ${ }^{43}$ Nonetheless, the Supreme Court's pronouncements up to that poimt indicated that the House subcommittee's fear that Bruton required the exclusion of imculpatory statements was without foundation. Bruton stated explicitly that its holding did not reach the case in which an exception to the hearsay rule was involved. ${ }^{44}$ If inculpatory statements fell within a hearsay exception-the issue which the

time to amending the rules than did the House subcommittee. The committee held two hearings in June 1974, reporting the bill in October. The bill passed 69-0 in November 1974.

39. Id.

40. Id.

41. Id. at 22 .

42. CONFERENCE REPORT, supta note 17 , at 12.

43. See generally California v. Green, 399 U.S. 149 (1970).

44. We emphasize that the hearsay statement imculpating petitioner was clearly not adinissible agaimst him under traditional rules of evidence...., the problem arising only because the stateinent was . . . admissible against the declarant Evans. . . . There is not before us, therefore, any recognized exception to the hearsay rule imsofar as petitioner is concerned and we intimate no view whatsoever that such cxceptions necessarily raise questions under the Confrontation Clause.

Bruton v. United States, 391 U.S. 123, 128 n.3 (1968).

The saine point was made in Dutton v. Evans, 400 U.S. 74, 86 (1970). It has been acknowledged by the federal courts of appeals. E.g., United States v. Kelley, 526 F.2d 615, 620 (8th Cir. 1975), cert. denied, 424 U.S. 971 (1976) ("Bruton involved no recognized exception to the hearsay rule. Indeed it has become well settled that the Bruton rule is limited to circumstances where the out-of-court statements are inadmissible . . . ."). 
committees had the power and responsibility to resolve-Bruton by its very terms would not apply. Moreover, the relationship between the confrontation clause and hearsay exceptions had been examined in Dutton v. Evans. ${ }^{45}$ Dutton held that the admission of a coconspirator's statement pursuant to an exception to the hearsay rule, in a trial in which the coconspirator did not testify, did not violate the confrontation clause. ${ }^{46}$ Though the opinion was far from clear, it histed a number of factors which would permit the admission of a statement by a declarant not available for cross-examination. In Dutton, and once more in a subsequent decision, ${ }^{47}$ the Court emphasized that the presence of sufficient indicia of rehability would satisfy the requirements of the confrontation clause. ${ }^{48}$

This case law demonstrates that the congressional committees, in dealing with inculpatory statements, were concerned with what they should have recognized as a phantom issue. Had they decided that inculpatory stateinents were to be included within the $804(\mathrm{~b})(3)$ excep-

45. 400 U.S. 74 (1970).

46. Id. at $87-88$.

47. Mancusi v. Stubbs, 408 U.S. 204, 213 (1972).

48. The Dutton plurality opinion is not a model of clarity. The opinion is an almost random recitation of the factors which the Court claimed insured that the defendant's confrontation clause rights were not violated. Many of the factors presented were apparently chosen simply because they were present in earkier cases finding violations and absent here. 400 U.S. at 87 . Nonetheless the plurahty did emphasize one factor whose source it was confident could be found in the principles underlying the confrontation clause: the presence of indicia of rehability. The opinion argucd that "indicia of reliability were widely viewed as determinative of whether a statement may be placed before the jury though there is no confrontation of the dcclarant." Id. at 89 . It continued: "The decisions of this Court make it clear that the mission of the Confrontation Clause is to advance a practical concern for the accuracy of the truth-deternining process in criminal trials by assuring that 'the trier of fact has a satisfactory basis for evaluating the truth of the prior statement." Id. The plurality concluded that the integrity of the truth-determining process liad not been undermined here because of the presence of indicia of reliability. Id.

In Mancusi v. Stubbs, 408 U.S. 204 (1972), this was the one strand of Dutton that was reiterated. The Court there defined its confrontation clause inquiry as follows: "The focus of the Court's concern has been to insure that there are "indicia of reliability which have been widely viewed as determinative of whether a statement may be placed before the jury though there is no confrontation of the declarant' ...."Id. at 213.

The federal courts of appeals, though occasionally alluding to a few other Dutton factors, basically have adopted reliability as the benchmark. If the statement admitted is sufficiently marked by indicia of reliability as to insure the accuracy of the truth-finding process, the confrontation clause is not violated. United States v. Martinez, 573 F.2d 529 (8th Cir. 1978); Umited States v. Weaver, 565 F.2d 129, 135 n.7 (8th Cir. 1977), cert. denied, 434 U.S. 1074 (1978); United States v. Haynes, 560 F.2d 913, 916 (8th Cir.), cert. denied, 434 U.S. 974 (1977); United States v. Scholle, 553 F.2d 1109, 1119-20 (8th Cir.), cert. denied, 434 U.S. 940 (1977); United States v. King, 552 F.2d 833, 845-46 (9th Cir. 1976); United States v. Carlson, 547 F.2d 1346, 1356 (8tlı Cir. 1976), cert. denied, 431 U.S. 914 (1977); United States v. Kelley, 526 F.2d 615, 620-21 (8th Cir. 1975), cert. denied, 424 U.S. 971 (1976); United States v. Snow, 521 F.2d 730, 734-36 (9th Cir. 1975). In many of these cases, the fact that the statement is against penal interest is cited as the main inark of reliability. See Dutton v. Evans, 400 U.S. 74, 89 (1970); United States v. Scholle, 553 F.2d at 1120; United States v. Kelley, 526 F.2d at 621; United States v. Snow, 521 F.2d at 73436. 
tion, Bruton would not have been directly applicable, and Dutton suggested that the confrontation clause issue would be resolved by the courts on a case-by-case basis. Had they not placed inculpatory statements within the 804(b)(3) exception, such stateinents would have been inadmissible hearsay, and the confrontation clause issue would never be reached.

\section{Conclusion}

Because of this misplaced emphasis on the confrontation clause, the congressional committees failed to address the issue of the reliability of inculpatory statements. Gaining a clear view of congressional intent on the inclusion of mculpatory statements within the 804(b)(3) exception is, therefore, difficult. Nonetheless, one can draw certain conclusions by combining observations about all of the drafting bodies. The more plausible view is that inculpatory statements are included in the 804(b)(3) exception. First, the rule in its final forin does not limit the adinission of statements against penal interest in a manner suggesting exclusion of inculpatory statements. Second, the Advisory Coininittee Note clearly specifies that statements truly against interest are admissible under $804(\mathrm{~b})(3) .{ }^{49}$ Finally, no congressional coinmittee asserted that inculpatory stateinents were not sufficiently reliable to be admitted under a hearsay exception. ${ }^{50}$ The more persuasive view, therefore, is that the drafters intended inculpatory statements to be admissible.

II

\section{The Application of Rule 804(b)(3)}

The admissibility of inculpatory statennents under rule 804(b)(3) has not been clarified by the federal courts' application of the rule. Experiencing difficulty interpreting and applying the explicit 804(b)(3) language about exculpatory statements, the federal courts liave been even inore tentative in deciding how to deal with inculpatory stateinents. An examination of the ways in which the federal courts have treated inculpatory and exculpatory statements under 804(b)(3) will illustrate this confusion and make evident the need for a solution to the inculpatory statement dilemma.

49. The Halpern-Frampton argument denigrating the committee's work as a legitimate source of an interpretation of rule $804(b)(3)$ is based on inadequate evidence. By itself, the argument is not sufficiently persuasive to raise significant doubts about the committee's position on the issue.

50. One may also wonder why both houses addressed the Bruton question if they intended to exclude inculpatory statements from the reach of the 804(b)(3) exception. If Congress had intended to place such statements outside the exception, the confrontation clause would have been irrelevant. Such statements would have been left as inadmissible hearsay. 


\section{A. Federal Case Law on Inculpatory Statements}

Few federal appellate cases have considered the admissibility of inculpatory statements under rule 804(b)(3). The clearest pronouncements on admissibility have appeared in dicta; where the issue has been squarely raised, courts have been evasive or unclear. In United States $v$. White, ${ }^{51}$ for example, the defendant was convicted of interstate transportation of two women for the purpose of prostitution. At trial two statements of one of the wolnen were admitted. ${ }^{52}$ The declarant was unable to testify because she had been killed before trial. The statements presented to the jury imdicated that the declarant had been a prostitute and had accompanied the defendant across state lines-evidence highly damaging to the defendant. Addressing the inculpatory statements issue, a Second Circuit panel in dicta discussed the arguments for and against admitting this evidence. ${ }^{53}$ But the court did not decide the case on these grounds. The court concluded that it did not need to decide whether the statements were admissible, argumg unpersuasively that the evidence did not have much impact on the factfinder ${ }^{54}$ The court thus avoided the thorny imculpatory statements issue by loolding that the admission of the statements was "if error at all, harmless." 55

In United States $v$. Rogers, ${ }^{56}$ the declarant admitted that he used defendant's identification to buy a gun and participated with the defendant in the robbery for which the defendant was convicted. ${ }^{57}$ The trial court admitted the statement for the limited purpose of impeaching the declarant. ${ }^{58}$ On appeal the defendant argued that the admission of the statement for even this limited purpose was erroneous. The government contended that rule 804(b)(3) allowed the admission of the statement not only to impeach the declarant but also as substantive evidence. $^{59}$ The Court of Appeals for the Eighth Circuit upheld the trial court's admission of the statement for impeachment, ${ }^{60}$ and therefore did not have to address the government's 804(b)(3) argument. The

51. 553 F.2d 310 (2d Cir.), cert. denied, 431 U.S. 972 (1977).

52. One statement was a comment made to an FBI agent who testified at trial; the other was a written statement summarized by the same agent. Id. at 312 .

53. The court referred to arguments against including inculpatory collateral statements (one was Weinstein's position), and also to the omission of the final sentence. Id. at 313-14. The court also asserted erroneously that the House of Representatives had deleted the final sentence. Id. at $313 \mathrm{n} .8$. This mistake is noteworthy because it is a minor, but pointed, example of the carelessness of some federal courts in dealing with rule 804(b)(3) and inculpatory statements.

54. Id. at 314.

55. Id.

56. 549 F.2d 490 (8th Cir. 1976), cert. denied, 431 U.S. 918 (1977).

57. Id. at 494 .

58. Id. at 497 .

59. Id. at 498 n.8.

60. Id. at 498 . 
court nevertheless noted that the declarant's admission of an illegal purchase of a gun ${ }^{61}$ might not have been against interest because the declarant might have viewed cooperation with law enforcement officials as in his interest. ${ }^{62}$ The court concluded that the trial judge, in light of the suspect reliability of the statement, did not abuse the discretion granted by Federal Rule of Evidence 403 to exclude a statement when the statement's probative value is outweighed by its potential prejudicial effect. ${ }^{63}$

The court's treatment of this question is confusing and subject to conflicting interpretations. Its analysis can be read to indicate that inculpatory statements are admissible under $804(\mathrm{~b})(3)$ but that in this case the possible unreliability of the statement justified exclusion based on rule 403. On the other hand, the court did not directly state that inculpatory statements were admissible. Its discussion could with equal plausibility be characterized as simply determining that the trial court's refusal to admit the inculpatory statement involved a proper exercise of discretion in the instant case. In this view the question of the admissibility of the inculpatory statement under 804(b)(3) was not reached. Addressing the inculpatory statement problem though the case did not require it, the court tlus avoided taking a clear position and produced further confusion.

Only two federal opinions have made a clear statement about the admissibility of inculpatory statements under rule 804(b)(3). Each court determined that sucli stateinents were admissible, ${ }^{64}$ although in each case the conclusion was dictum. In United States $v$. Barrett, ${ }^{65}$ the court briefly described the background of rule 804(b)(3) and noted Congress' deletion of the final sentence. It concluded that the omission meant that "subject to sixth amendment and other constraints, a third party's out-of-court stateinents against penal interest may now be used

61. The declarant's statement that he had participated in the robbery was not truly against interest because the declarant had already pleaded guilty to the robbery. His admission therefore did not subject him to additional criminal liability.

62. 549 F.2d at 498 n.8.

63. Professor Rotlustein's description of the case misrepresents its holding, providing another example of the confusion this problem has caused. In P. ROTHSTEIN, Practice Comments: Rules of Evidence for the UNITEd States Courts and Magistrates 386.1 (June 1977), Professor Rothstem describes the case as follows: "(co-criminal's statement identifying defendant as accomplice; no good; that part not agaimst interest.)" Professor Rothstein's language suggests that the court viewed the collateral inculpatory portion as not admissible because it by itself was not against the declarant's imterest. This is true of all collateral inculpatory statements, suggesting that Rogers excludes all collateral inculpatory statements on this ground. Quite to the contrary, the Rogers court expressed doubt about whether the against interest portion of the statement was sufficiently disserving. It did not argue that the collateral portion could not be against interest. For the present federal law on the point, see text accompanying notes 70-81 infra.

64. For a case in which a state supreme court reached the same conclusion, see People v. Edwards, 396 Mich. 551 , 556 n.43, 242 N.W.2d 739, 746 n.43 (1976).

65. 539 F.2d 244 (Ist Cir. 1976). 
against, as well as in favor of, an accused."66 United States $v$. Hyde involved a claim that a wiretap order had been issued without probable cause. $^{68}$ In finding that probable cause did exist, the court observed that one informant's statement had been against penal interest. The court argued that "804(b)(3) . . . declares such statements admissible in spite of the hearsay rule (thus acknowledging their reliability)."

The federal judiciary has inade poor use of the opportunities presented to clarify the reach of $804(\mathrm{~b})(3)$. The cases discussed above nevertheless suggest that inculpatory statements will be held to be admissible in soine circuunstances. Howeyer, these cases provide no indication of the guidelines that will govern the admissibility determination. It would seem that such guidelines might be apparent in federal cases involving exculpatory statements under 804(b)(3). In fact, those decisions provide little guidance because they are inconsistent and unclear. Examining these cases nevertheless illustrates this confusion and suggests the basis for its elimination in cases concerning inculpatory statements.

\section{B. Federal Case Law on Exculpatory Statements}

The inconsistency of the federal courts in determining the admissibility of exculpatory statements is evident in their treatment of three important issues: the admissibility of collateral ${ }^{70}$ statements; the extent to which a statement against penal interest must be disserving; and the degree of corroboration necessary before the exculpatory stateinent can be admitted.

\section{Collateral Statements}

Cases arising before the promulgation of rule 804 (b)(3) held that collateral exculpatory stateinents were not admissible as declarations against penal interest. ${ }^{71}$ These cases held the collateral portion to be not against interest, and therefore inadmissible, regardless of the relationship between the disserving and collateral statements. ${ }^{72}$ The cases appearing since the promulgation of the Federal Rules of Evidence

66. Id. at 250.

67. 574 F.2d 856 (5th Cir. 1978).

68. Id. at 862 .

69. Id. at 863 .

70. For a description of collateral and noncollateral statements, see note 7 supra.

71. Park v. Huff, 493 F.2d 923, 932 n.17, rev'd on rehearing en banc, 506 F.2d 849 (5th Cir.), cert. denied, 423 U.S. 824 (1974); United States v. Marquez, 462 F.2d 893, 895 (2d Cir. 1972); United States v. Seyfried, 435 F.2d 696, 697-98 (7th Cir. 1970), cert. denied, 402 U.S. 912 (1971).

72. In United States v. Marquez, 462 F.2d 893, 895 (2nd Cir. 1972), the declarant had stated: "Cocame nime. Other guys had nothing to do with it. Got cocame yesterday. Don't know who I got it from." Despite the close relationship between the disserving and collateral exculpatory portions, the court characterized then as severable, with only the directly disserving portion ("cocaine mine") admissible. 
have for the most part ignored the problem. The text of rule 804(b)(3) by itself provides little guidance and would accommodate comfortably eitlier a doctrine excluding or one admitting collateral statements. ${ }^{73}$ No federal court of appeals has refused to admit a declaration against penal interest under rule 804(b)(3) because a collateral statement was involved. However, declarations against penal interest have been admitted in a number of cases even though the relevant information was contained in a collateral statement.

United States v. Benveniste ${ }^{74}$ provides an illustration. The Court of Appeals for the Ninth Circuit reversed a conviction because the trial court failed to admit an exculpatory collateral statement. The disserving portion of the declarant's statement was an admission that she was involved in a drug sale. The exculpatory portion of the statement contained assertions about the conduct of the defendant and an informant at the sale which aided the defendant. ${ }^{75}$ These assertions were clearly collateral to, and severable from, the disserving portions. Nonetheless, the court ignored the collateral statements issue, implicitly determining that exculpatory collateral statements are admissible under 804(b)(3).

In United States $v$. Barrett, ${ }^{76}$ the Court of Appeals for the First Circuit explicitly held collateral statements to be adinissible subject to certain requirements. The court reviewed the debate about the reliability of collateral stateinents and concluded that exclusion was not warranted. ${ }^{77}$ It appeared to the court that Congress did not intend to exclude collateral statements, thougli the court did not substantiate its claim witl a discussion of the history of $804(\mathrm{~b})(3) .^{78}$ Where the collateral portion is "sufficiently integral to the entire statement," the court concluded, botli the collateral and noncollateral portions constitute a statement against interest under the rule. ${ }^{79}$

Barrett is the only decision appearing since the effective date of the rules to formulate explicitly a rule admitting collateral statements. It represents, along with one other decision relying on the rule while it was being drafted ${ }^{80}$ the beginning of a new line of authority. Because

73. CAL. EvID. CODE $§ 1230$ contains almost identical language about declarations against penal interest, and the California Supreme Court has held that collateral statements arc not admissible under that provision. People v. Leach, 15 Cal. 3d 419, 441, 541 P.2d 296, 311, 124 Cal. Rptr. 752, 767 (1975).

74. 564 F.2d 335, 341-42 (9th Cir. 1977).

75. The declarant's statement suggested that the defendant was not an active party in the sale, bolstering the defendant's entrapment defense. Id. at 341 . The statement also contradicted the informant's testimony, thereby damaging her eredibihty.

76. 539 F.2d 244 (1st Cir. 1976).

77. Id. at 252 .

78. Id. at 253.

79. Id.

80. United States v. Goodlow, 500 F.2d 954 (8th Cir. 1974). The analysis in Goodlow is 
the prerules cases hold to the contrary, ${ }^{81}$ the issue has not yet been clearly resolved by the federal courts.

\section{The Extent to Which a Statement Against Penal Interest Must Be Disserving}

The federal courts also have failed to articulate a consistent standard in describing the extent to which a statement must be disserving in order to qualify as a declaration against penal interest. Two conflicting approaches are apparent in the cases.

A liberal approach was einployed in United States v. Barrett. ${ }^{82}$ The declarant had said that he and two others "were going to have some trouble froin the people from California' with respect to the 'stamp tlieft or inatter." "83 The statement was disserving because it demonstrated declarant's knowledge of the stamp theft and the identity of the participants, thereby suggesting that he inay liave been involved in the criminal venture. ${ }^{84}$ The statement nevertheless was not a compelling.link between the declarant and the crime. Realizing this, the court declared that the agamst penal interest exception did not demand a confession. Since the stateinent contaimed "important evidence" harmful to the declarant should he ever be prosecuted, the court concluded that it was sufficiently disserving to qualify under rule 804(b)(3). ${ }^{85}$

The Barrett approach lias been adopted in other cases. In United States v. Thomas ${ }^{86}$ the declarant had stated that the defendant "didn't have anything to do with [the crime]." 87 The court claimed the state-

neither elaborate nor clear, but it does state the court's conclusion that the collateral statement involved there was admissible: "Such a statement, standing alone, is only exculpatory as to Goodlow and, as such, constitutes inadmissible hearsay. . . . However, simce the statements allegedly were inade at the saine time and within the same context of [declarant's] adinission of guilt, their overall exclusion or admission should be considered as one." $500 \mathrm{F.2d}$ at 956.

81. See cases cited in note 71 supra .

82. 539 F.2d 244, 249 (Ist Cir. 1976).

83. Id.

84. Id.

85. See id. at 251, where the court stated: "Though by no ineans conclusive, the statement would be important evidence against [the declarant] were he himself on trial for the stamp crimes. We cannot say, therefore, that it did not pose the sort of threat to [declarant's] interest that the hearsay exception contemplates."

For another case taking the same approach, see Umited States v. Benveniste, 564 F.2d 335 (9th Cir. 1977). The declarant there stated that she had introduced the key government witness to two drug dealers at her apartinent, apparently aware that all parties were contemplating a drug sale. The court argued: "Out of context, however, the specific statements she inade to defendant's investigator which contradict the informant would not alone be against her penal interest. We do not believe, however, that rule 804 (b)(3) was intended to apply only to statements which amount to direct confessious of criminal responsibility. Otherwise Congress would not have used the broadly worded phrase "tended to subject." "Id. at 341.

86. 571 F.2d 285 (5th Cir. 1978).

87. Id. at 288. 
ment was disserving because it "implie[d] that the declarant had knowledge of the crime," and concluded that statements "that would have probative value in a trial agamst the declarant" 88 are sufficiently disserving to be admitted under rule 804(b)(3). ${ }^{89}$

The court in United States $v$. Pena ${ }^{90}$ applied a much more demanding standard. The declarant was an informant who allegedly bore a grudge agamst the defendant." In his statement, he admitted "setting up" the defendant as a party to a heroin sale and keeping the money provided by the government to facilitate the sale. ${ }^{22}$ The defendant argued that the statement was admissible since the declarant's admission that he kept the funds supplied by the government left him vulnerable to an embezzleinent charge. ${ }^{93}$ The court rejected this argument. Noting that "there are possible explanations of [the declarant's] receipt of money which are imconsistent with culpability on his part,"94 the court found that the statement was not against interest. Emphasizing that the statement alone and out of context could not support declarant's conviction, the court held the statement inadmissible. ${ }^{95}$

Under the Barrett-Thomas line of authority, the statement of the declarant in Pena would have been admissible as against penal imterest. The stateinent did contain "evidence of probative value in a trial against the declarant." The Pena court's argument that the statement was not disserving because there were possible explanations which were inconsistent with the declarant's culpability contrasts sharply with the Barrett-Thomas approach. There surely were "other possible" explanations for the declarants' knowledge of the crimes in Barrett and Thomas which would not have implicated them in criminal activity. The statements were nonetheless admitted. Thus federal courts have failed to articulate a consistent standard.

\section{Corroboration Requirement}

The federal courts' treatınent of the corroboration requirement of rule $804(b)(3)$ for exculpatory stateinents ${ }^{96}$ also has been unsatisfactory. The provision requiring corroboration was added to the rule in the

88. Id. at $288-89$.

89. Id. at 289. United States v. Satterfield, 572 F.2d 687 (9th Cir. 1978), similarly rejected a "restrictive approach" because Congress required only that the statement "fended to subjeet" the declarant to criminal habihty. Id. at 691 (emphasis in original).

90. 527 F.2d 1356 (5th Cir. 1976).

91. Though the case was tried before the passage of the rules, the court assumed arguendo that it could choose to follow rule $804(\mathrm{~b})(3)$.

92. 527 F.2d at $1359-60$.

93. Id. at 1361.

94. Id.

95. Id. at 1361-62. See also United States v. Hoyos, 573 F.2d 1111 (9th Cir. 1978) (to be admissible, a statement must subject declarant to penal liability in a "real and tangible way").

96. FED. R. Evid. 804(b)(3) provides: "A stateinent tending to expose the declarant to crimi- 
October 1971 Advisory Committee draft and strengthened by the House subcommittee. ${ }^{97}$ The addition of the corroboration requirement reflected the lingering distrust of declarations against penal interest, the feeling that some additional mark of reliability was needed before such evidence could be confidently admitted. ${ }^{98}$ The federal courts have failed to agree on what quantum of corroboration is required. ${ }^{99}$

One approach to the corroboration requirement was used in Lowery v. Maryland. ${ }^{100}$ The declarant stated in an affidavit that he had perjured himself in important testimony against the defendant. The defendant sought to have the affidavit admitted in support of his petition for habeas corpus. The court conceded that the declarant's perjury admission was against his penal interest. It acknowledged that corroborating circumstances suggesting reliability were present. ${ }^{101}$ The court nevertlieless argued that other facts in the case undermined the credibility of the statement ${ }^{102}$ and refused to admit it. Instead of setting forth a corroboration standard requiring a prima facie slowing of reliability and leaving the ultimate determination of credibility to a jury, the court einployed a balancing test, admitting only statements

nal liability and offered to exculpate the accused is not admissible unless corroborating circumstances clearly indicate the trustworthiness of the statement."

97. Along with advocating the omission of the final sentence, Senator McClellan also proposed a corroboration requirement. See Supplement to House Hearings, supra note 27, at 60 (letter from Senator John McClellan to Judge Albert B. Maris, (Aug. 12, 1971)). A corroboration requirement was added in the October 1971 draft and appeared in the final Advisory Committee draft. See Proposed Fed. R. Evid. 804(b)(4) (1972 draft), 56 F.R.D. 183, 321 (1972). The present language, strengthening the standard by requiring a clear indication of trustworthiness, was added by the House subcommittee. Proposed Fed. R. Evid. 804(b)(3), Tentative Subcommittee Draft of H.R. 5463 in Supplement to House Hearings, supra note 27, at 175.

98. House RePORT, supra note 15, at 15; Advisory Committee's Note to Proposed Fed. R. Evid. 804(b)(4) (1972 draft), 56 F.R.D. 183, 327 (1972).

99. In fact, as with other aspects of 804(b)(3), soine courts have misconccived completely the focus of the requirement because of a misunderstanding of the theory behind the rule. In United States v. Atkins, 558 F.2d 133 (3d Cir. 1977), cert. denied, 434 U.S. 1071 (1978) and United States v. Bagley, 537 F.2d 162 (5th Cir. 1976), cert. dented, 429 U.S. 1075 (1977), statements were excluded because the making of the statement, rather than its content, was not corroborated. This reasoning is specious because the witness testifying about the making of the statement is before the court, under oath, and subject to cross-examination. As to the making of the statement, the witness' testimony is not hearsay, and corroboration should not be required. In United States $v$. Atkins, the court of appeals chided the trial court for requiring corroboration of the witness' testimony describing the inaking of the declaration. However, in reversing because of the exclusion of what it apparently viewed as a reliable statenent, the court histed evidence which only corroborated the contention that the statement had been made, not that its content was true. $558 \mathrm{~F} .2 \mathrm{~d}$ at 135-36. The same error is made in United States v. Bagley, 537 F.2d at 167.

100. 401 F. Supp. 604 (D. Md. 1975), affd mem., 532 F.2d 750 (4th Cir.), cert. denied, 429 U.S. 919 (1976).

101. Id. at 608. The factors were: the declaration was a sworn statement; the declarant was a person who had been at the scene of the crime and lad knowledge of the occurrence; and the defendant had testified that the declarant's testimony at trial had been coerced.

102. Id. These were: the declarant had been in prison with the defendant; the statement was inade three and one-half years after the trial and was not "spontaneous"; and the police officers claimed that declarant's testimony at trial had not been coerccd. 
found credible by the court after evaluating all of the surrounding circumstances. ${ }^{103}$

A inore liberal approach was used in United States $v$. Barrett. ${ }^{104}$ The court conceded that it had little guidance from existing law in defining the scope of the corroboration requirement. Though aware that the drafters viewed the requirement as "not an insignificant hurdle," it refused to define the requirement as "so strict as to be utterly unreahistic." ${ }^{105}$ Judge Jack Weinstein's position may suggest what the court had in mind. Weinstein has argued that evidence indicating the declarant's physical proximity and willingness to commit the crine should suffice if such evidence would persuade a "reasonable man . . . that the statement might have been made in good faith and that it could be true." 106 In contrast to Lowery, this approach does not require that the court balance those facts corroborating the declarant's statement with those undermining its rehability. ${ }^{107}$ Rather, it allows for admission once a threshold of corroboration has been passed. The jury is left to nake the balance.

\section{Conclusion}

Because the federal cases dealing with the admissibility of exculpatory statements have taken varied approaches and reached divergent conclusions, these cases do not aid significantly the effort to determine how inculpatory statements should be treated. Thus, neither the drafting history of rule 804(b)(3) nor the federal case law on statements against penal interest is very helpful to one attempting to develop a

103. For other cases employing a similarly restrictive corroboration test, see United States v. Satterfield, 572 F.2d 687, 693 (9th Cir. 1978); United States v. Oropeza, 564 F.2d 316 (9th Cir.), cert. denied, 434 U.S. 1080 (1977); United States v. Guillette, 547 F.2d 743 (2d Cir. 1976), cert. denied, 434 U.S. 839 (1977). Oropeza and Guilette unsuccessfully attempt to graft the reliability considerations listed in Chambers v. Mississippi, 410 U.S. 284 (1973), onto the corroboration requirement. Chambers held that the exclusion of a hearsay statement which was against the declarant's interest, circumstantially trustworthy, and important to the defendant's defense violated the due process clause. Id. at 302-03. In the process, the Court histed considerations indicating the trustworthiness of the statement. Guillette summarized the considerations as follows: (1) when and to whom was the statement made; (2) was there corroborating evidence; (3) is the dcclaration really against the declarant's interest; and (4) is the declarant available. 547 F.2d at 754. The incorporation of these considerations into the corroboration requirement is redundant. Considerations two through four are explicitly covered in 804(b)(3), and consideration one is irrelevant because the witness will be subject to cross-examination. This incorporation simply leads to evasion and confusion. The use of this approach often will obscure the basis upon which a decision rests, with a court stating that there is insufficient corroboration when what is really meant is that the statement is not disserving.

104. 539 F.2d 244 (1st Cir. 1976).

105. Id. at 253 . The discretion of the trial judge in applying the requirement was also emphasized by the court.

106. $4 \mathrm{~J}$. WEINSTEIN, supra note 7, [ 804(b)(3)[03] at 804-90.

107. In fact the court in Lowery expressly rejected Wcinstein's view. 401 F. Supp. 604, 607 (D. Md. 1975), affd mem., 532 F.2d 750 (4th Cir. 1976), cert. denied, 429 U.S. 919 (1977). 
coherent approach to inculpatory statements under the rule. Alternative approaches must be examined, and a prescription for dealing with inculpatory statements under $804(\mathrm{~b})(3)$ must be advanced. It is to this task that we next turn.

\section{III}

\section{Alternative Approaches}

Although the issue was barely considered in the drafting of rule 804 (b)(3), ${ }^{108}$ much of the debate about inculpatory statements in the literature and state decisions has centered on the reliability of collateral statements. ${ }^{109}$ Only those believing collateral statements to be marked by reliability sufficient to overcome the doubts embodied im the hearsay rule have favored admission. Because very few noncollateral inculpatory statements appear in the cases, ${ }^{10}$ the exclusion of collateral statements would cause the exclusion of almost all inculpatory statements. Therefore, a conclusion about the reliability of collateral statements is the underpinning of any rule determining the admissibility of inculpatory statements.

Professor Joln H. Wigmore ${ }^{111}$ and Bernard S. Jefferson ${ }^{112}$ (now a California appellate court justice) have advanced the conflicting views concerning the admissibility of collateral statements which have gained the most support. Professor Wigmore argued that a statement against mterest mdicates that the declarant is im a trustworthy state of mind, and that all additional statements made while the declarant remams in this state are reliable and should be admitted into cvidence. ${ }^{113}$ The Model Code of Evidence adopts this basic approach. The relevant provision admits "a declaration against interest and such additional parts thereof, including matter incorporated by reference, as the judge finds so closely connected with the declaration against imterest as to be equally trustworthy."114

108. The altemating inclusion and exclusion of the final sentence of $804(b)(3)$ was effected with little refercnce to whether the relevant material of the statement introduced was contained in the disserving or the collateral portion. The final sentence would have explicitly excluded collateral and noncollateral inculpatory statements. See notes 9-49 and accompanying text supra.

109. The hearsay exception for stateinents agaimst pecuniary or proprietary interest has been available for much longer than that for statements against penal interest. As a result, the treatinent of collateral statements in the context of pecuniary and proprietary statements is inuch more extensive. The general rule has been one of admissibility of neutral and even, on occasion, of selfserving collateral statements. See RICHARDSON, supra note 2 , at $\$ 299 ; 5$ J. W1GMORE, supra note 2 , at $\$ 1465$; Jeffcrson, supra note 6 , at 56-60.

110. See note 7 supra.

111. $5 \mathrm{~J}$. WIGMORE, supra note 2.

112. Jefferson, supra note 6.

113. See 5 J. WIGMORE, supra note 2. See also Morgan, The Rationale of Vicarious Admissions, 42 HARV. L. REV. 461, 480-82 (1929).

114. MODEl CODE OF EVIDENCE Rule 509(2) (1942). 
Though no state statutes have adopted the language, a number of state courts have admitted collateral statements in criminal cases. Admission has been achieved in various ways. In State v. Parrish ${ }^{115}$ the Supreme Court of Kansas held that an inculpatory collateral statement was admissible. The court simply asserted that the statement was agamst interest and that "testimony of the preliminaries and circumstances leading up to and surrounding the making of the assertion" were admissible. ${ }^{116}$ No analysis of the issue was attempted. ${ }^{117}$

A more sophisticated treatment of the collateral statement question reaching the same result appears in State $v$. Abrams. ${ }^{118}$ The New Jersey Supreme Court there affirmed and adopted the reasoning of a lower appellate court which admitted into evidence a collateral exculpatory statement. ${ }^{119}$ The lower court argued that as long as the entire statement was agaimst penal interest, exclusion should not result merely because a portion of that statement by itself did not subject the declarant to penal liability. ${ }^{120}$ The relevant facts were here contained in the collateral portion. Three judges on the seven-judge New Jersey Supreine Court concurred and dissented in separate opinions addressing the collateral statement question more directly. In essence, the

- 115. 205 Kan. 178, 468 P.2d 143 (1970).

116. Id. at 183,468 P.2d at 148 . The testimony consisted of statements by the declarant that the defendant had offered to pay him to burn down a hotel. Id. at 179-82, 468 P.2d at 145-47. The court held that the statements indicating the declarant's involvement in the arson plan were against his interest. However, the fact that it was the defendant who made the offer was not against the declarant's interest. It was this collateral portion that was relevant in the trial of the defendant and that had been admitted by the trial court.

117. In an opinion which also did not discuss the collateral statement issue raised by the declaration admitted, three concurring judges of the seven-judge New York Court of Appeals argued that an inculpatory collateral statement should be admitted. People v. Harding, 37 N.Y.2d $130,135-37,332$ N.E.2d 354, 357-59, 371 N.Y.S.2d 493, $497-99$ (1975) (concurring opinion). The statement consisted of an admission that the declarant was a numbers runner and had been picked up by the defendant, a policeman. It related that the declarant had contacted her "banker," who had arranged for her release by bribing the policeman. The defendant policeman continued to extort money from the declarant's boss, leading to his arrest and conviction for that conduct. Id. at 136-37, 332 N.E.2d at 358, 371 N.Y.S.2d at 497-98. Here, the admission by the declarant of her "numbers" sale was the disserving portion of the statement. The assertion that the declarant witnessed the defendant accepting a bribe from her "banker" was collateral. The majority did not reach the issue because it held the admission of the statement harmless error, if error at all. Id. at 134,332 N.E.2d at 357,371 N.Y.S.2d at 496.

118. 140 N.J. Super. 232, 356 A.2d 26 (1976), affd, 72 N.J. 342, 370 A.2d 852 (1977).

119. The inajority affirmed "substantially for the reasons expressed" in the lower court opinion. 72 N.J. at $342,370 \mathrm{~A} .2 \mathrm{~d}$ at 852 . The statement involved was a declaration that " "I . . sold [the detective] a bag of cocaine, but I didn't and never got nothing from [the defendant]." " 140 N.J. Super. at $235,356 \mathrm{~A} .2 \mathrm{~d}$ at 27 . The collateral portion exculpating the defendant was the relevant segment.

120. The lower court stated: "The rule does not require that each discrete part of the statement inply involveinent in a crime . . ." 140 N.J. Super. at 235-36, 356 A.2d at 28 . It later added: "The appropriate test for admissibility is whether, in the context of the whole statement, the particular remark was plausibly against the declarant's penal interest, even though it might be neutral or even self-serving if considered alone." Id. 
three judges argued that the collateral portion should be admitted if it were integrally related to the disserving portion. ${ }^{121}$ The three dissented because they believed that the determination of the degree of interrelationship between the collateral and disserving portions should be made by the trial court, not the appellate court. ${ }^{122}$

Wigmore's position has an undeniable appeal. His approach provides useful flexibility because it allows a judge some discretion in determining whether the trustworthiness evidenced by the disserving fact underlies closely related assertions. This flexibility seems desirable when one begins to examine statements in the cases which appear to be the products of minds so immersed in confession as to be immune from the sway of dissembling forces. ${ }^{123}$ However, several considerations indicate that the wholesale adoption of Wigmore's approach by the federal courts is neither likely nor desirable.

An important obstacle preventing ready admission of inculpatory statements is the questionable psychological premise upon which such a standard would be built. It is said to be a common sense conclusion that people generally do not concede facts against their interest unless such facts are true. ${ }^{124}$ But it is becoming increasingly obvious that there are numerous exceptions to this observation. In recent years, a number of individuals have confessed to crimes they did not commit. ${ }^{125}$ These individuals have ranged from psychotics to pranksters, from publicity seekers to drug ingesters. ${ }^{126}$ Many actually beheved that they

121. One concurring and dissenting justice, citing Wignore and the Model Code of Evidence stated: "That next step calls for inquiry into whether the exculpatory part of the statement (or separate exculpatory declaration) should be permitted to 'tag along' with the inculpatory part under the doctrine of continuing trustworthiness." 72 N.J. at 343,370 A.2d at 852 . This opinion was joined by one other justice. The other concurring and dissenting opinion made the same point: "If [the declaration] . . . was essentially a single, integral stateinent such that the trustworthiness of the portion admitting liability rubbed off on the portion absolving [the defendant] of connection with the criminal transaction, it should be adinissible." Id.

122. Id. at 343, 370 A.2d at 853-54.

123. In the following cases, the image presented by the facts is of an individual speaking of things harmful and painful, emotionally upset, defenses down, baring all. The presence of such statements and accompanying circumstances in the cases suggests that there is some validity in Wiginore's argument. In United States v. White, 553 F.2d 310 (2d Cir. 1977), cert. denied, 431 U.S. 972 (1977), the court depicted the declarant's statements as those of a friglitened, vulnerable person, exposing herself to criminal liability in conversations in which she did not have the selfpossession or the desire to lie. In People v. Ireland, 38 Ill. App. 3d 616, 348 N.E.2d 277 (1976) the declarant was similarly shaken when she stated to the defendant's parents (her in-laws) that she, and not the defendant, had obtained and owned the marijuana, for the possession of which the defendant had been arrested. Id. at 618,348 N.E.2d at 279. Note that the declarant's exculpation of the defendant was collateral to her admission of her own guilt, since both she and the defendant could have been guilty of procuring and possessing the marijuana.

124. See Note, Declarations Against Interest-Rules of Admissibility, 62 Nw. U.L. REv. 934, 941 n.34 (I968).

125. Timnick, False Murder Confessions: Reasons Why, L.A. Times, Mar. 12, 1978, at 1, col. 1. See generally T. REIK, The CoMpulsion to Confess (1959).

126. Id. 
had committed the crime and, consequently, stated their guilt in a persuasive inanner. These individuals are the irrational, those not encompassed in our common sense conclusions based on observations of reasonable people. ${ }^{127}$ They are too numerous, and the potential effect of their testimony is too potent, to be ignored. ${ }^{128}$

The reliability of declarations against penal interest is further attenuated in inculpatory statements made in police custody. Ostensibly damaging confessions are frequently self-serving in that environinent. ${ }^{129}$ Accusing others is readily perceived as a way to gain favor with law enforceinent officials. A conspiracy gone awry can easily generate enough enmity to induce the captured unfortunate to exaggerate the role of those only peripherally involved. ${ }^{130}$ The potential for false accusations is evident.

Even when inculpatory statements are not made in police custody, the presence of certain factors inay diminish their reliability. Cominitting a crime constitutes an achievement of great magnitude to some people. The temptation to falsify a claim of criminal success to impress colleagues cannot be ignored. ${ }^{131}$ Other psychological motives may also produce unreliability. Persons adnntting to a crime they have in fact committed nay subconsciously feel that their culpability is diminished if they implicate others. In this instance, an ostensibly disserving statement actually would be self-serving.

The reluctance to admit exculpatory statements has long been justified by the fear that declarants intending to flee a state might falsely implicate themselves in order to free an accused comrade or thwart the criminal justice syste1n. ${ }^{132}$ This fear is equally applicable to inculpatory stateınents-a revenge seeker might reveal imagined joint crimes before departing a state. In addition, the veracity of a significant source of testimony presenting inculpatory statements may be suspect. Informants and undercover agents, who often liave an interest in securing a conviction, may fabricate or distort facts in their testimony. ${ }^{133}$

127. Two courts have expressed the same fear. See Ward v. Pitt, [1913] 2 K.B. 130, 138; People v. Leach, 15 Cal. 3d 419, 441, 541 P.2d 296, 311, 124 Cal. Rptr. 752, 767 (1975).

128. Recall that rule 804(b)(3) can be invoked only when the declarant is unavailable. Hence an individual might admit involvement in a crime, then depart from the jurisdiction and remain unavailable for examination about his mental state.

129. Bruton v. United States, 391 U.S. 123, 141-42 (1968) (White, J., dissenting).

130. The commentators have been very sensitive to this phenomenon. See Levie, Hearsay and Conspiracy, 52 Mich. L. Rev. 1159, 1173 (1954); Comment, Preserving the Right to Confrontation-A New Approach to Hearsay Evidence in Criminal Trials, 113 U. PA. L. Rev. 741, 755.56 (1955).

131. United States v. Atkins, 558 F.2d 133 (3d Cir. 1977), cert. denied, 434 U.S. 1071 (1978), provides an example of a statement against penal interest that was probably a boast.

132. C. MCCoRMICK, supra note 2, at § 278; 5 J. WIGMORE, supra note 2, at § 1477.

133. People v. Edwards, 396 Mich. 551, 566 n.43, 242 N.W.2d 739, 746 n.43 (1976). The court stated:

Undercover agents and informers are professional dissemblers. Their assignment is to 
The declarant is not present to contradict such testimony. Though cross-exammation is available to expose untrustworthy testimony, the familiarity of undercover agents with the trial process can reduce the effectiveness of the cross-examination.

Wigmore's position has not gained the unanimous approval of the legal community. Jefferson's contrary approach ${ }^{134}$ has commanded significant support. Jefferson found untenable Wigmore's justification for the majority rule. $\mathrm{He}$ insisted that the rehability of the statement against interest stems from the disserving fact stated. Jefferson rejected the notion that a disserving statement reflects a trustworthy state of mind extending beyond the confines of the disserving portion of the statement. ${ }^{135}$ Because only the statement of the disserving fact bears the requisite indicia of reliability, Jefferson insisted, only that portion should be admitted.

Jefferson's arguments have persuaded some legislatures ${ }^{136}$ and courts. ${ }^{137}$ The California Supreme Court relied on Jefferson's reasoning in holding that collateral statements are not admissible. ${ }^{138}$ In State

take on a false identity and so convincingly act a lie that they gain the confidence of alleged drug dealers, fences and murderers. Frequently their very lives depend upon their ability to play a particular role. These same persons, skilled in the art of dissembling, then come into court and repeat statements allegedly made to them which inculpate defendants. Often they are cooperating with the authorities in an effort to win concessions regarding charges pending against them; many are paid; others "cooperate" with the police because they are morally outraged by the conduct defendant is alleged to have engaged in. Leniency, pay, and vindication of moral convictions could well be related to success in the particular assignment; there is a motive for the agent or informant to make the case he or she knows the authorities want.

134. Jefferson, supra note 6.

135. Id. at 57-63.

136. See, e.g., ME. Rev. Stat. tit. 14, § 804(b)(3) (Supp. 1978); N.J. Stat. ANN. § 63(10) (West Supp. 1978); N.D. Cent. Code \$ 804(b)(3) (Supp. 1977).

137. For a prerules federal case adopting Jefferson's approach, see United States v. Seyfried, 435 F.2d 696, 698 (7th Cir. 1970), cert. denied, 402 U.S. 912 (1971): "Where a statement is clearly separable, part of which is against one's interest and part is not, only that part which is against one's interest and, therefore, has some inherent trustworthiness should be adinitted." See also Park v. Huff, 493 F.2d 923, 932 n.17, rev'd on rehearing en banc, 506 F.2d 849 (5th Cir.), cert. denied, 423 U.S. 824 (1974).

138. People v. Leach, 15 Cal. 3d 419, 441, 541 P.2d 296, 311, 124 Cal. Rptr. 752, 767 (1975). This position was advanced in the face of statutory silence sinilar to that of rule $804(\mathrm{~b})(3)$. The court concluded:

In the absence of any legislative declaration to the contrary, we construe the exception to the hearsay rule relating to evidence of declarations against interest set forth in section 1230 of the Evidence Code to be mapplicable to evidence of any statement or portion of a statement not itself specifically disserving to the interests of the declarant.

Id. at 441,541 P.2d at 311,124 Cal. Rptr. at 767. Much of the reasoning justifying the court's holding is presented in the form of long quotations from Jefferson's piece. Id. at $439 \mathrm{n} .15,541$ P.2d at 309 n.15, 124 Cal. Rptr. at 765 n.15. The court's effort to buttress Jefferson's position with additional argumeuts was not successful. Noting that the purpose of the hearsay rule is to exclude stateinents of unreasonable people, Chief Justice Wright suggested that adinitting the instant statement involved crediting the reliabihty of an unreasonable person. Id. at $441-42,541$ P.2d at $311-12,124$ Cal. Rptr. at 767-68. The fiaw in this reasoning is that it had little to do with the issue addressed by the court, the reliability of collateral statements. The only conclusion Clief Justice 
v. Self ${ }^{139}$ the New Mexico Supreme Court also held collateral statement inadmissible. Though the court did not rely expressly on Jefferson's article, its reasoning provides a clear example of his approach. The court severed the collateral part of the statement because only the disserving portion was rehable and admissible. The court's aversion to collateral statements was shown by its narrow, though proper, identification of the disserving portion. The declarant admitted obtaming a gun froin the defendant, who was accused of stealing that gun. ${ }^{140}$ The stateinent subjected the declarant to criminal liability in two ways: the declarant's status as a felon made his possession of a gun illegal; his admission also constituted evidence of the crime of knowingly receiving stolen property. The court msisted that both of these disserving aspects stemmed solely froin the declarant's possession of the gun. The identity of the thief supplying the weapon, which was the only fact relevant to the defendant's trial, did not affect the declarant's potential penal hability. The statement was therefore not agamst interest, not reliable, and not admissible. ${ }^{141}$

Jefferson's proposal to exclude all collateral statements has the virtue of being easily apphicable. Moreover, Jefferson's reasoning-that only the portion of the statement containing disserving facts is rehable-seems cogent because it is the disserving character of the facts that inspires trust. However, Jefferson's approach, like that of Wigmore, is not a satisfactory resolution of the 804(b)(3) problem. First, the drafting history of the rule suggests that Jefferson's approach was probably not that intended by the drafters. ${ }^{142}$ Second, no federal appellate case dealing with the issue under the rules has reached Jefferson's conclusion. ${ }^{143}$ Finally, blanket exclusion of collateral statements would deprive the against penal interest exception of inuch of its force. Because a large number of exculpatory statements are collateral, ${ }^{144}$ Jefferson's approach would limit significantly the utility of rule $804(\mathrm{~b})(3)$. It is

Wright's argument supported is that all declarations against penal interest, since inade by unreasonable people (ie., criminals), are untrustworthy and should be excluded. This surely is not what the court intended to say.

139. 88 N.M. 37, 536 P.2d 1093 (1975).

140. Id. at 40,536 P.2d at 1096.

141. Id. at $41-42,536$ P.2d at 1097-98. Contrast this careful severance of the disserving from the collateral portion with the lax treatment of the question by a court inore hospitable to exculpatory collateral statements. The declarant in Commonwealth v. Carr, 1977 Mass. Adv. Sheets 2312, 369 N.E.2d 970, stated he had been involved in a drug sale but the defendant had not. The state's evidence showed that both were involved. The court treated the entire statement as disserving and did not perceive that the portion exculpating the defendant was collateral to the disserving portion.

142. See section IC supra.

143. See notes 80-81 and accompanying text supra.

144. See, e.g., statements in cases discussed in text accoinpanying notes $71,72,80,115-17$, 119 , and 123 supra, and in notes $74-75,82-84,140-41$ supra. 
unlikely that the federal courts would be willing to so eviscerate the against penal interest exception.

Though neither Wigmore's nor Jefferson's approach could, in its absolute form, serve as the governing standard under rule 804(b)(3), the viewpoints of both scholars provide a basis for building an appropriate guideline under the rule. The standard advanced in the following section represents a circumspect acceptance of the proposition that inculpatory statements should be admissible. It reflects a fusion of two views: first, that inculpatory statements are sufficiently reliable as a general proposition to warrant admission; second, that the failure to be sensitive to the potential unreliability of specific inculpatory statements may result in the deprivation of an imdividual's liberty. The proposed standard embodies a reconciliation and synthesis of two central legal precepts. One is Wigmore's notion that it is the probability of trustworthiness found in statements excepted from the hearsay rule which satisfies us that such statements should be submitted to the jury for their determmation of credibility. ${ }^{145}$ The other is the traditional American deference to the criminal defendant. Based upon a wary acceptance of the view that inculpatory statements generally are sufficiently reliable for adinission, the standard contains stringent safeguards to eliminate the risk of convictimg a defendant by admitting an untrustworthy inculpatory statement.

\section{IV}

\section{STRICT SCRUTINY WITH CORROBORATION}

Inculpatory statements should be admitted under rule 804(b)(3) if they can pass a "strict scrutiny with corroboration" test. Under this test, the disserving portion would be rigorously examined to inake certain that the statement is truly against interest. In addition, the proponent of the statement would have to show that the collateral portion is so closely related in time and context to the disserving portion that it is equally trustworthy. Finally, the corroboration requirement applied to exculpatory statements under 804 (b)(3) would be extended to inculpatory statements.

The careful examination and corroboration requireinents would impress upon judges that a significant degree of confidence in the reliability of a statement is necessary before tlie statement should be admitted. With the reasoning behind the approacli made clear, judges would be forced to deal with inculpatory statements in a consistent, sound manner. This approach would ensure that the jury would not be denied exposure to probative evidence, while adequately safeguarding the criminal defendant's rights.

145. 5 J. WIGMORE, supra note 2 , at $§ 1422$. 


\section{A. Strict Scrutiny}

This standard demands that judges examine closely a claim that an inculpatory statement is sufficiently agamst interest to be trustworthy. The proponent would have to show that the statement directly and clearly imphicates the declarant in a crime. A statement containing a single piece of circumstantial evidence suggestimg culpabihty would not suffice. People v. Traylor ${ }^{146}$ illustrates how this standard would be applied. The court there upheld the exclusion of an exculpatory statement in which a declarant admitted he was present in a car in which lieroin was found. The court held that the fact admitted had to be "distinctly" against interest, not simply a link im a probative chain. ${ }^{147}$ Since admitting his presence at the scene of the crime did not directly implicate the declarant as the owner of the heroin, the statement was excluded. ${ }^{148}$

The strict scrutiny standard also demands that the reasonable person language of rule $804(\mathrm{~b})(3)$ be apphed with sufficient flexibihity to enhance the likelihood of reliability. Rule 804(b)(3) requires that the declaration be sufficiently against interest that a reasonable person in the position of the declarant would not have inade the statement unless it were true. ${ }^{149}$ Under strict scrutiny, the court would evaluate the specific context in which the statement was made in determining whether the statement was actually against interest. This examination would result in the exclusion of statements which are ostensibly agamst interest, but which, because of the circumstances in which they are made, are eitlrer neutral or self-serving. Thus, by considering the environment in which the stateinent was made, the judge would be able to

146. 23 Cal. App. 3d 323, 100 Cal. Rptr. 116 (2d Dist. 1972).

147. Id. at 331,100 Cal. Rptr. at 120 . For a discussion of the contrasting federal approaches to this question with exculpatory statements, see text accompanying notes 82-95 supra. The "significant evidence" test of Barrett is, obviously, inconsistent with the "direct implication" guideline advanced here.

148. The statement in Dutton v. Evans, 400 U.S. 74 (1970), provides another example of how the strict scrutiny standard would operate. To avoid the mistake of the Advisory Committee and the congressional committees, it should be noted that though the case was a confrontation clause case, the focus here is solely on the statement, and not on the confrontation clause principles announced by the Court. The declarant in Dutton said: "If it hadn't been for [the defendant], we wouldn't be in this now." Id. at 77. The statement had been admitted under a Georgia coconspirator's exception to the hearsay rule. In its analysis, the plurality opinion stated that the statement was against the declarant's penal interest. Id. at 89 . The dissent, noting that the defendant had earlier antagonized the local pohice, argued that the statement was ambiguous. It might simply have refiected the declarant's belief that he and the defendant were being harassed because the police disliked the defendant. Under the strict scrutiny standard, the proponent in this case would not have been able to show that the statement directly and clearly implicated the declarant. Therefore, the statement would not have been admissible.

At the other end of the continuum is the statement in United States v. Marquez, 462 F.2d 893, 895 (2d Cir. 1972): "Cocaine inine." This clearly indicated guilt.

149. FED. R. EvID. 804(b)(3). 
detect and exclude statements which were jokes or boasts. ${ }^{150}$ To the extent that courts have been willing to exclude statements to police admitting crimes because they suspect the declarant is attempting to secure better treatment, this approach is already being applied. ${ }^{151}$

Strict scrutiny also would permit an examination of the traits of the particular declarant to verify that the statement is likely to be rehable. First, tlie opponent of the evidence would be allowed to show that the declarant was not aware that tlie statement was disserving. Second, the opponent would be allowed to show that this declarant was not the "reasonable person" contemplated by rule 804(b)(3). If the opponent could show that the declarant was, for example, intoxicated or deranged, the disserving nature of the statement would provide no assurance of reliability, and the statement would not be admitted. ${ }^{152}$ By requiring that the opponent of admission prove the presence of these "subjective" elements, strict scrutiny would not obstruct the proponent's effort to introduce evidence, ${ }^{153}$ but would insure that the statement was marked by indicia of trustworthiness.

Finally, strict scrutiny would require careful examination of the interrelationship between the disserving and collateral portions of the declaration. The trial judge and appellate court would have to examine carefully the circuinstances surrounding the making of the statement to make certain that the entire declaration was a single reliable pronouncement. ${ }^{154}$

150. See, e.g., United States v. Atkins, 558 F.2d 133 (3d Cir. 1977), cert. denied, 434 U.S. 1071 (1978). Atkins involved an exculpatory statement. The declarant, a minor, stated to a group of young people on a street comer outside a bar that he had been involved im a robbery which had just occurred and had killed a guard. The trial judge excluded the statement. The justification for the exclusion was not stated clearly, aud the judge was reversed by the court of appeals for focusing solely upon the credibility of the witness testifying about the content of the declarant's stateinent. Id. at 135-36. What the court of appeals overlooked was that the district judge had in fact coneluded that the statement was not disserving. Reviewing the context in which the statement was inade, the judge apparently had determined that the statement was likely a boast and hence self-serving: "[T]hose kind [sic] of statemeuts made by minors in the presence of other minors sometimes are in the interest of minors to inake." $I d$. at 135 . Strict scrutiny would require a judge to examine the surrounding circumstances to detect and exclude such statements.

151. See Bruton v. United States, 391 U.S. 123, $141-42$ (1968) (White, J., dissenting).

152. Strict scrutimy also would permit a related examination of the declarant's motive to lie. Wigmore and Jefferson disagree about how to handle this factor. Wigmore treats it as a part of the against interest determmation. $5 \mathrm{~J}$. WIGMORE, supra note 2, at $\S 1464$. Jefferson treats it as a separate consideration. Jefferson, supra note 6, at 53-55. Under strict scrntiny, if the opponent could show that the declarant had a motive to lie sufficient to negate the presumption of trustworthiness, the statemeut would not be adinitted.

153. The desire to avoid imposing on the proponent the burden of showing that the declarant was aware that the statement was disserving played a role in the fashioning of the qualified reasonable inan standard of rule 804(b)(3). See House Hearings, supra note 25, at 59 (statement of Albert Jeımer).

154. For an example of the kinds of circumstances which would satisfy this requirement, see note 123 supra. 


\section{B. Corroboration}

The second major component of this standard is the requirement of corroboration. Under rule 804(b)(3), exculpatory statements must be corroborated. ${ }^{155}$ Identical treatment of exculpatory and inculpatory statements is proper here ${ }^{156}$ because neither type of statement is more reliable than the other. ${ }^{157}$ The degree of corroboration required for exculpatory statements under rule $804(\mathrm{~b})(3)$ is unclear. ${ }^{158}$ This proposal adopts the stringent balancing test employed in Lowery v. Maryland ${ }^{159}$ rather than the more liberal standard advocated by Judge Weinstein. ${ }^{160}$ Caution about the reliability of declarations agamst penal interest justifies use of the balancing test. Allowing judges to find corroborating evidence inadequate because its credibility is undermined by other evidence would ensure that the fair trial rights of the defendant were protected with minimal harm to the factfinding process.

\section{CONCLUSION}

Determining how inculpatory statements should be treated under rule $804(\mathrm{~b})(3)$ emerges as a frustratimg endeavor. An examination of the drafting of the rule reveals that an madequate understanding of the issue pervaded the drafting process. The confusion spawned by the drafters is reflected in the tentative and inconsistent way the federal courts have applied the rule. Ultimately, the effort to construct a workable standard under the rule still leaves a feeling of frustration, a sense that one has addressed a problem on terms inhospitable to a cogent and just solution. The Advisory Committee's indication that inculpatory statements should be admitted ${ }^{161}$ shifts the focus of discourse to an arena in which it is alnost impossible to achieve a satisfactory resolution. Liberal adinission of inculpatory stateinents is unacceptable because the doubts about the consistent trustworthiness of inculpatory

155. FED. R. EvID. 804(b)(3).

156. The absence of a reference to corroboration for mculpatory statements in the rule can be attributed to the confused treatment of the inculpatory statement issue by the drafters. The proposal for a corroboration requirement for exculpatory statements was advanced when the Advisory Committee draft excluded inculpatory statements. Supplement to House Hearings, stupra note 27, at 60 (letter from Senator John L. McClellan to Judge Albert B. Maris). It is quite likely that with the simultaneous addition of a corroboration requirement and omission of the final sentence, the logical expansion of the requirement to inculpatory statements was simply overlooked.

157. See Washington v. Texas, 388 U.S. 14, 22-23 (1967). The court stated: "To think that criminals will he to save their fellows but uot to obtain favors from the prosecution for themselves is indeed to clothe the criminal class with more nobility than one might expect to find in the public at large."

158. See notes 96-107 and accompanying text supra.

159. 401 F. Supp. 604 (D. Md. 1975), affd mem, 532 F.2d 750 (4th Cir. 1976), cert. denied, 429 U.S. 919 (1977). See notes 100-03 and accompanying text supra. See also United States v. Satterfield, 572 F.2d 687, 693-94 (9th Cir. 1978).

160. $4 \mathrm{~J}$. WeINSTEIN, supra note 7. See notes 106-07 and accompanying text supra.

161. See notes $19-24$ and accompanying text supra. 
statements are sound. The effort here has been to suggest a standard addressed to those doubts, one designed to eliminate the more common sources of unreliability. The strict scrutiny with corroboration standard does have drawbacks. Time will be consumed in the process of weeding out unreliable statements. However, this effort is necessary to protect the defendants' fair trial rights, given that the Advisory Committee Note and the federal case law suggest that liberal admissibhty is the only alternative. If the drafting history indicated that another option were present, the response might be different.

Ultimately, this examination of inculpatory statements and rule 804(b)(3) may contain a lesson relevant beyond the immediate problem. The hearsay exception for declarations against penal interest, like other hearsay exceptions, is based on an untested, cominon sense assumption about human psychology. ${ }^{162}$ The simplicity of this assumption has led to its ready acceptance. The major works dealing with the exception rarely dissect the rationale belimd the rule, and increasing knowledge of the human psyche has created significant doubt about that assumption. ${ }^{163}$ Yet those who drafted the rule seem not to have evaluated fully the conceptual basis for the exception. The intent here has been to address a concrete problem and present a practical solution. The broader hope is that an awareness of the specific dilemina will inspire others to reexamine the against penal interest exception and put it on rational footing.

Michael D. Bergeisen*

162. For a classic piece attacking a similar basis for the spontaneous utterance exception, see Hutchins \& Slesinger, Some Observations on the Laws of Evidence, 28 ColuM. L. REv. 432 (1928).

163. See notes 125-26 and accompanying text supra.

* A.B. 1976, University of Cahifornia, Berkeley; third-year student, Boalt Hall School of Law; Research and Book Review Editor, California Law Review. 
